\title{
PENINGKATAN HASIL PRODUKSI KERTAS MENGGUNAKAN PENDEKATAN DESCRETE EVENT SIMULATION (STUDY KASUS PT XYZ)
}

\author{
Mio Yoga Misvian Mahar Dejan \\ e-mail : mioyoga17@gmail.com \\ Teknik Industri, FakultasTeknik \\ Universitas Maarif Hasyim Latif
}

\begin{abstract}
ABSTRAK
PT. XYZ merupakan perusahaan berkembang yang ada di Jawa Timur dan menjalankan bisnisnya sebagai perusahaan manufaktur dengan produk berupa kertas. Perusahaan memiliki target hasil produksi yang harus tercapai di setiap harinya.Metode yang digunakan adalah dengan pendeketan discrete event simulation yang diawali dengan pembuatan model awal yang sesuai dengan kondisi nyata kemudian dilanjutkan dengan membuat model perbaikan sebagai usulan, metode ini dianggap dapat mensimulasikasin sistem produksi. Dari hasil penelitian yang telah dilakukan dapat diketahui bahwa hasil produksi kondisi eksisting sebesar 157.5 ton sedangkan hasil output usulan sebesar 247.8 ton sehingga ada peningkatan sebesar $57.3 \%$ atau 90.3 ton rata rata per hari.
\end{abstract}

Kata kunci : hasil produksi, discrete event simulation

\section{PENDAHULUAN}

Kertas menjadi item yang mengambil peranan penting didalam kehidupan manusia. PT. XYZ merupakan salah satu perusahaan kertas yang berlokasi di Gresik, Jawa Timur. PT XYZ sempat mengalami vacum produksi karena terjadi masalah internal. Namun saat beroperasi kembali PT. XYZ belum mampu mengikuti persaingan dalam dunia bisnis di bidang kertas. Perusahaan mamemiliki kebijakan untuk meningkatkan kegiatan produksi.

Dalam menghasilkan sebuah produk kertas, PT. XYZ memiliki sebuah rangkaian mesin produksi yang cukup panjang, sehingga tidak menutup kemungkinan pada bagian-bagian mesin terjadi masalah atau kerusakan yang tidak dapat diprediksi (Riyanto, 2016). Ketika sistem produksi terjadi masalah sangatlah berpengaruh pada hasil produksi. Perusahaan telah menetapkan target sebesar 200 ton perhari namun output terkadang hasil produksi belum dapat mencapai angka 200 ton. Untuk mencapai target atau menigkatkan hasil produksi maka perlu diadakan sebuah pengkajian analitis (Santoso \& Fudhla, 2019). Dalam mencari solusi untuk masalah atau pengaruh kapasitas hasil produksi bukanlah hal mudah, sehingga menerapkan metode simulasi kejadian diskrit (descrete event simulation) merupakan salah satu langkah yang dapat mengatasi masalah yang terjadi (Suprianto dkk, 2018). Software arena telah banyak digunakan untuk memperbaiki kinerja suatu proses produksi manufaktur maupun sistem pelayanan atau jasa (Riyanto, 2016). Sehingga dapat dijadikan salah satu opsi dalam meningkatkan hasil produksi dan daya saing di industri kertas.

\section{METODE PENELITIAN}

\section{DESCRETE EVENT SIMULATION}

Discrete Event Simulation (DES) merupakan suatu peoses perilaku sistem yang kompleks dan memiliki urutan yang teratur dari peristiwa yang telah di definisikan dengan baik (Suprianto dkk, 2018). Dalam konteks ini sebuah peristiwa terdiri dari perubahan yang spesifik dalam kondisi tertentu. Event yang ada didalam DES menggambarkan sebuah aliran proses, aliran proses adalah suatu urutan kejadian yang berfungsi melakukan simulasi sehingga event akan menciptakan keterlambatan dalam simulasi untuk mereplika satu jalur waktu yang memicu pada kejadian terjadwal dan kejadian kondisional (Muhammad \& Suryani, 2018). Menurut Rustam dkk (2015) Proses Discrete Event Simulation yang efektif meliputi beberapa hal, yaitu :

1. Penentuan titik awal dan titik akhir, dimana kejadian diskrit menggunakan satuan waktu.

2. Suatu metode untuk melacak waktu yang sudah berlalu sejak proses dimulai

3. Suatu peristiwa diskrit yang terjadi sejak proses dimulai

4. Daftar peritiwa diskrit yang tertunda hingga proses yang diharapkan berakhir.

5. Sebuah catatan statistik atau grafik dari fungsi simulasi kejadian diskrit saat ini.

Analisis kejadian diskrit didalam proses manufaktur dan layanan antrian dengan mengunakan permodelan. Permodelan sistem merupakan suatu proses membuat sebuah model dari sebuah kejadian nyata. Dalam simulasi kejadian diskrit perubahan status model simulasi terjadi pada waktu yang diakibatkan oleh kejadian diskrit (Muhammad \& Suryani, 2018). Menurut Kusnandar \& Perdana (2014) Terdapat beberapa komponen penyusun Discrete event simulasi, yaitu : 


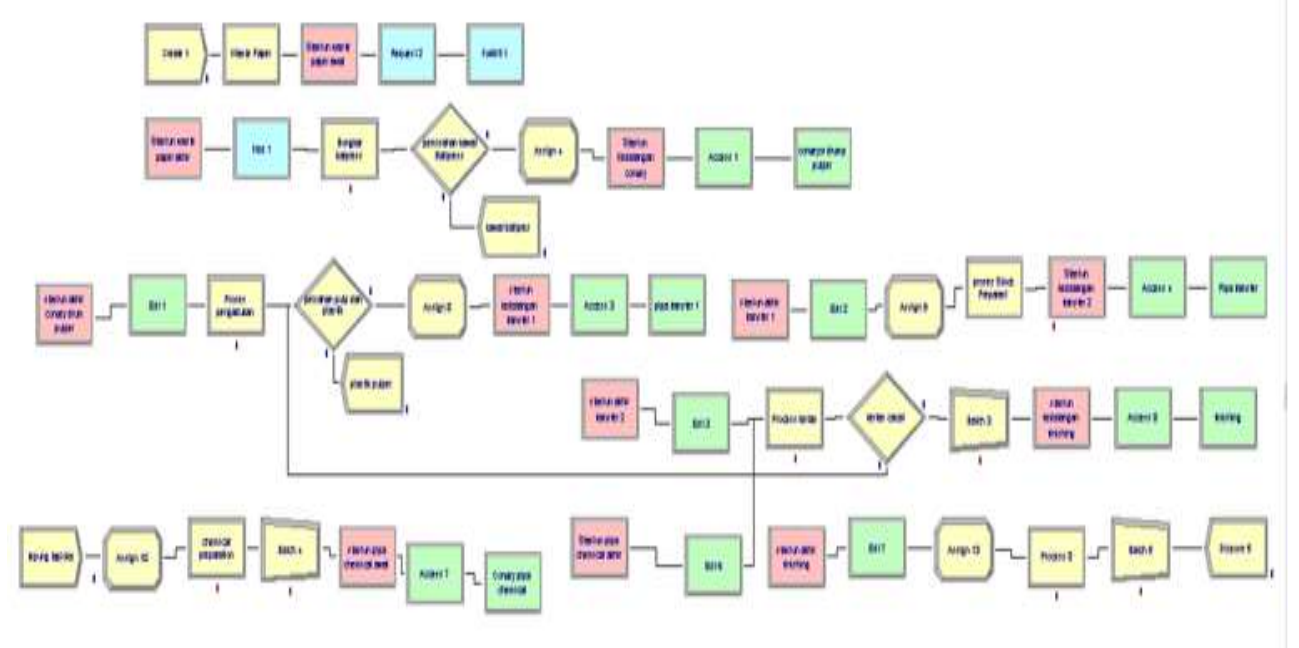

Gambar 1. Penyusunan Model Awal

1. Work (entity) adalah suatu bagian kerja, material, ataupun pelanggan yang terdapat didalam sistem untuk mendapatkan pelayanan.

2. Recource merupakan proses melanyani entity yang berupa mesin ataupun tenaga kerja.

3. Rouing adalah sebuah rute suatu proses yang harus dilewati oleh entity

4. Buffe merupakan suatu tempat berkumpulnya entity sebelum diproses oleh recource.

5. Schedulig merupakan suatu pola waktu yang dimiliki recource saat beroperasi

6. Sequencig adalah sebuah urutan sebelum entity di proses

7. Performnce ialah pungukuran dari kinerja sistem.

\section{HASIL DAN PEMBAHASAN}

Pada gambar 4.2 menjelaskan proses produksi kertas memiliki tahapan proses mesin dan juga memiliki waktu transfer untuk memindahkan entitas ke proses selanjutnya, proses transfer dilakukan dengan menggunakan transporter dan conveyor. dalam gambar diatas tahapan yang berwarna kuning muda merupakan tahapan pemrosesan entitas sedangkan tahapan yang berwarna pink, biru dan hijau merupakan tahapan transfer entitas.

\section{Validasi}

Validasi model model dilakukan dengan tujuan memastikan bahwa model telah mampu memenuhi simulasi dan sistem nyata yang dapat diwakili oleh model simulasi dengan menggunakan uji prilaku model atau uji t (2 sampel).
Uji prilaku model atau uji t (2 sampel) digunakan untuk menghitung perbedaan interval antar dua populasi, ketika populasi standar penyimpangan $\sigma$ 's tidak diketahui, maka untuk uji t (2 sampel) adalah sebagai berikut. Sampel yang digunakan adalah output dari sistem produksi selama 30 hari dan replikasi simulasi dalam 30 hari.

\begin{tabular}{|c|c|c|c|c|}
\hline \multirow{2}{*}{ Days } & \multicolumn{2}{|c|}{ Data real } & \multicolumn{2}{|c|}{ Model awal } \\
\hline & ROLL & TON & ROLL & TON \\
\hline 1 & 22 & 154 & 23 & 161 \\
\hline 2 & 22 & 154 & 22 & 154 \\
\hline 3 & 17 & 119 & 18 & 126 \\
\hline 4 & 20 & 140 & 18 & 126 \\
\hline 5 & 23 & 161 & 21 & 147 \\
\hline 6 & 24 & 168 & 25 & 175 \\
\hline 7 & 23 & 161 & 31 & 217 \\
\hline 8 & 23 & 161 & 19 & 133 \\
\hline 9 & 22 & 154 & 19 & 133 \\
\hline 10 & 20 & 140 & 22 & 154 \\
\hline 11 & 22 & 154 & 21 & 147 \\
\hline 12 & 22 & 154 & 22 & 154 \\
\hline 13 & 17 & 119 & 21 & 147 \\
\hline 14 & 20 & 140 & 20 & 140 \\
\hline 15 & 17 & 119 & 17 & 119 \\
\hline 16 & 25 & 175 & 23 & 161 \\
\hline 17 & 24 & 168 & 23 & 161 \\
\hline 18 & 29 & 203 & 25 & 175 \\
\hline 19 & 24 & 168 & 26 & 182 \\
\hline 20 & 12 & 84 & 17 & 119 \\
\hline 21 & 25 & 175 & 27 & 189 \\
\hline 22 & 28 & 196 & 24 & 168 \\
\hline 23 & 20 & 140 & 24 & 168 \\
\hline 24 & 26 & 182 & 26 & 182 \\
\hline 25 & 25 & 175 & 22 & 154 \\
\hline 26 & 28 & 196 & 24 & 168 \\
\hline 27 & 26 & 182 & 24 & 168 \\
\hline 28 & 20 & 140 & 24 & 168 \\
\hline 29 & 25 & 175 & 23 & 161 \\
\hline 30 & 26 & 182 & 24 & 168 \\
\hline $\mathrm{AVG}$ & 22,57 & 157,97 & 22,5 & 157,5 \\
\hline MIN & 12 & 84 & 17 & 119 \\
\hline MAX & 29 & 203 & 31 & 217 \\
\hline
\end{tabular}


Tabel 2. Validasi model

Independent Samples Test

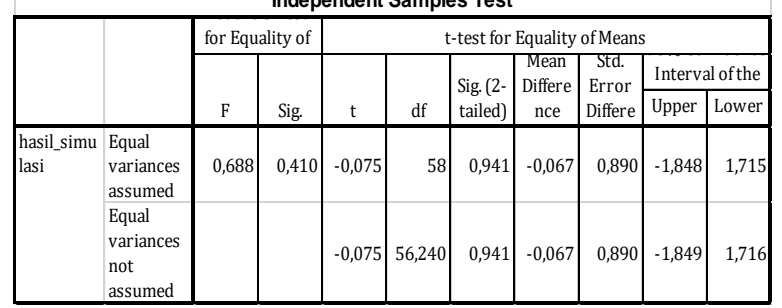

Berdasarkan hasil uji parameter model (uji t 2 sampel) sampel yang terlihat nilai $\mathrm{p}$ - value sebesar 0.941 karena nilai P-value lebih besar dari nilai $\alpha=0.05$ yang berarti $\mathrm{HO}$ diterima, sehingga dapat disimpulkan bahwa secara statistik tidak ada perbedaan antara data simulasi dengan data historis output produksi.

\section{Analisis Model Awal}

Dari hasil simulasi model awal ditemukan masalah yaitu rata-rata entitas ballpress yang masuk sebesar 201,8 ballpress namun entitas yang keluar dari ballpress hanya 90,4 ballpress dengan keaadan ini terdapat antrian ballpress yang tidak dapat diproses oleh checker (kelompok pekerja yg terdiri dari 4 orang) pada tahap proses pembongkaran ballpress. Berdasarkan tabel 2 menjelaskan probabilitas antrian ballpress dimana $\lambda$ adalah kedatangan ballpress dan $\mu$ adalah ballpress yang dapat diproses. Kode LQ (Long Queue) pada tabel diatas menjelaskan jumlah antrian ballpress yang terjadi, rata rata dari jumlah antrian ballpress tersebut sebesar -4.0473. Kemudian kode LS (Long System) menjelaskan jumlah ballpress yang terdapat dalam sistem atau ballpress yang sedang antri dan sedang dilayani, rata rata dari jumlah ballpress dalam sistem sebesar -1.8130 kemudian kode WQ (Waiting Queue) menjelaskan waktu tunggu yang terjadi dalam antrian, rata-rata waktu tunggu yang terjadi dalam antrian sebesar -0.0201. Kemudian WS (Waiting System) menjelaskan waktu tunggu ballpress yang sedang mengantri dan sedang dilayani, rata-rata waktu tunggu ballpress yang sedang dilayani sebesar 0.0090. Kemudian untuk kode PW (Probability Work) menjelaskan probabilitas fasilitas pelayanan atau waktu sibuk dalam 1 kelompok, rata-rata probabilitas layanan sebesar 2.2342 sedangkan standart waktu sibuk adalah 0>1 maka dapat diartikan bahwa waktu sibuk dari checker adalah 2 kali lipat dari jam normal. Simbol minus pada long queue, long system, waiting queue, waiting system menandakan bahwa kurangnya fasilitas pelayanan atau tenaga kerja.

Tabel 3. Analisis model awal

\begin{tabular}{|c|c|c|c|c|c|c|c|c|c|c|}
\hline DAY & $\bar{x}$ & $x^{\wedge}$ & $\mu$ & $(\mu-\lambda)$ & $\mu(\mu-\lambda)$ & LQ & LS & WQ & ws & PW \\
\hline 1 & 205 & 42025 & 87 & -118 & -10266 & $-4,09$ & $-1,74$ & $-0,02$ & $-0,01$ & 2,36 \\
\hline 2 & 198 & 39204 & 90 & -108 & -9720 & $-4,03$ & $-1,83$ & $-0,02$ & $-0,01$ & 2,20 \\
\hline 3 & 211 & 44521 & 95 & -116 & \begin{tabular}{|l}
-11020 \\
\end{tabular} & $-4,04$ & $-1,82$ & $-0,02$ & $-0,01$ & 2,22 \\
\hline 4 & 206 & 42436 & 96 & -110 & -10560 & $-4,02$ & $-1,87$ & $-0,02$ & $-0,01$ & 2,15 \\
\hline 5 & 210 & 44100 & 94 & -116 & \begin{tabular}{|l|}
-10904 \\
\end{tabular} & $-4,04$ & $-1,81$ & $-0,02$ & $-0,01$ & 2,23 \\
\hline 6 & 204 & 41616 & 86 & -118 & -10148 & $-4,10$ & $-1,73$ & $-0,02$ & $-0,01$ & 2,37 \\
\hline 7 & 191 & 36481 & 82 & -109 & -8938 & $-4,08$ & $-1,75$ & $-0,02$ & $-0,01$ & 2,33 \\
\hline 8 & 201 & 40401 & 90 & -111 & -9990 & $-4,04$ & $-1,81$ & $-0,02$ & $-0,01$ & 2,23 \\
\hline 9 & 207 & 42849 & 90 & -117 & -10530 & $-4,07$ & $-1,77$ & $-0,02$ & $-0,01$ & 2,30 \\
\hline 10 & 199 & 39601 & 93 & -106 & -9858 & $-4,02$ & $-1,88$ & $-0,02$ & $-0,01$ & 2,14 \\
\hline 11 & 202 & 40804 & 94 & -108 & -10152 & $-4,02$ & $-1,87$ & $-0,02$ & $-0,01$ & 2,15 \\
\hline 12 & 204 & 41616 & 93 & -111 & -10323 & $-4,03$ & $-1,84$ & $-0,02$ & $-0,01$ & 2,19 \\
\hline 13 & 197 & 38809 & 90 & -107 & -9630 & $-4,03$ & $-1,84$ & $-0,02$ & $-0,01$ & 2,19 \\
\hline 14 & 200 & 40000 & 92 & -108 & -9936 & $-4,03$ & $-1,85$ & $-0,02$ & $-0,01$ & 2,17 \\
\hline 15 & 206 & 42436 & 88 & -118 & -10384 & $-4,09$ & $-1,75$ & $-0,02$ & $-0,01$ & 2,34 \\
\hline 16 & 201 & 40401 & 95 & -106 & \begin{tabular}{|l}
-10070 \\
\end{tabular} & $-4,01$ & $-1,90$ & $-0,02$ & $-0,01$ & 2,12 \\
\hline 17 & 207 & 42849 & 95 & -112 & \begin{tabular}{|l}
-10640 \\
\end{tabular} & $-4,03$ & $-1,85$ & $-0,02$ & $-0,01$ & 2,18 \\
\hline 18 & 199 & 39601 & 88 & -111 & -9768 & $-4,05$ & $-1,79$ & $-0,02$ & $-0,01$ & 2,26 \\
\hline 19 & 192 & 36864 & 89 & -103 & -9167 & $-4,02$ & $-1,86$ & $-0,02$ & $-0,01$ & 2,16 \\
\hline 20 & 202 & 40804 & 88 & -114 & -10032 & $-4,07$ & $-1,77$ & $-0,02$ & $-0,01$ & 2,30 \\
\hline 21 & 201 & 40401 & 88 & -113 & -9944 & $-4,06$ & $-1,78$ & $-0,02$ & $-0,01$ & 2,28 \\
\hline 22 & 199 & 39601 & 88 & -111 & -9768 & $-4,05$ & $-1,79$ & $-0,02$ & $-0,01$ & 2,26 \\
\hline 23 & 197 & 38809 & 85 & -112 & -9520 & $-4,08$ & $-1,76$ & $-0,02$ & $-0,01$ & 2,32 \\
\hline 24 & 197 & 38809 & 91 & -106 & -9646 & $-4,02$ & $-1,86$ & $-0,02$ & $-0,01$ & 2,16 \\
\hline 25 & 205 & 42025 & 91 & -114 & -10374 & $-4,05$ & $-1,80$ & $-0,02$ & $-0,01$ & 2,25 \\
\hline 26 & 198 & 39204 & 85 & -113 & -9605 & $-4,08$ & $-1,75$ & $-0,02$ & $-0,01$ & 2,33 \\
\hline 27 & 208 & 43264 & 96 & -112 & -10752 & $-4,02$ & $-1,86$ & $-0,02$ & $-0,01$ & 2,17 \\
\hline 28 & 203 & 41209 & 89 & -114 & -10146 & $-4,06$ & $-1,78$ & $-0,02$ & $-0,01$ & 2,28 \\
\hline 29 & 205 & 42025 & 96 & -109 & -10464 & $-4,02$ & $-1,88$ & $-0,02$ & $-0,01$ & 2,14 \\
\hline 30 & 200 & 40000 & 89 & -111 & -9879 & $-4,05$ & $-1,80$ & $-0,02$ & $-0,01$ & 2,25 \\
\hline AVG & 201,83 & 40759 & 90,433 & $-111,4$ & -10071 & $-4,05$ & $-1,81$ & $-0,02$ & $-0,01$ & 2,23 \\
\hline
\end{tabular}

\begin{tabular}{|l|r|}
\hline Rata-rata jumlah ballpres dalam antrian (lq) & $-4,05$ \\
\hline Rata-rata jumlah ballpres dalam sistem (LS) & $-1,81$ \\
\hline Rata-rata waktu ballpres dalam antrian (WQ) & $-0,02$ \\
\hline Rata-rata waktu ballpres dalam sistem (WS) & $-0,01$ \\
\hline Probabilitas waktu sibuk (PW) & 2,23 \\
\hline
\end{tabular}

\section{Penyusunan Model Perbaikan}

Penyusunan model perbaikan merupakan pembuatan model dengan memperbaiki model awal berdasarkan masalah yang sudah di identifikasi dan di analisis sehingga dapat memenuhi tujuan penyusunan model perbaikan guna menjadi bahan pertimbangan pengambilan keputusan untuk kedepannya. Penyusunan model perbaikan dilakukan dengan 
mensimulasikan perubahan alur transfer ballpress yang awalnya ditransfer menggunakan forklift kini diubah menggunakan truck yang dapat mengangkut 6 ballpress dalam setiap pengiriman dan menambahkan 1 orang checker dalam proses bongkar ballpress.

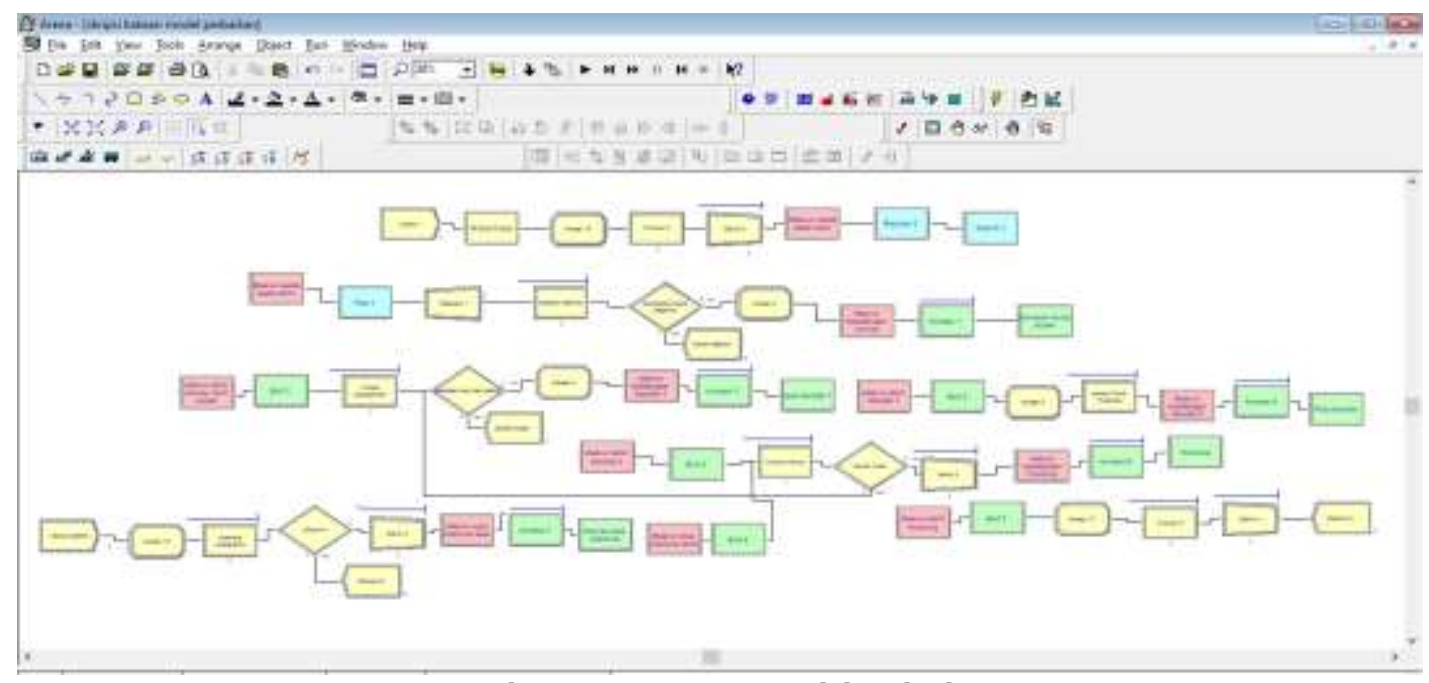

Gambar 2. Penyusunan model perbaikan

Dengan adanya perubahan alur transfer yang berawal dari transfer menggunakan forklift kemudian di ubah dengan menggunakan truck maka Pembuatan model perbaikan tidak jauh berbeda dengan model awal hanya menambahkan 1 modul proses yaitu proses loading dari storage menuju ke truck pengangkut ballpress dan menambahkan 1 checker pada modul proses pembongkaran ballpress sehingga total dari checker bongkar ballpres berjumlah 5 orang dan selebihnya masih sama dengan model awal.

Dari perubahan skema tersebut muncul hasil ballpress yang masuk sebanyak 139 ballpress dan diikuti ballpres yang keluar sebanyak 135 ballpress. Dari hasil model perbaikan ini ballpress yang masuk memang lebih sedikit dibandingkan dengan model awal namun jumlah ballpress keluar berada diatas model awal selain itu dengan penambahan 1 orang checker beban kerja dari checker menjadi seimbang antar checker, checker 1 mampu memproses 19 ballpress kemudian checker 2 mampu memperoses 21 ballpres kemudian checker 3 mampu memproses 20 ballpress kemudian checker 4 mampu memproses 21 ballpress dan checker 5 mampu memproses 21 ballpres. Output hasil simulasi mengalami peningkatan dengan rata rata output sebesar 35.4 mini roll atau sebesar 247.8 ton jika model direpilkasi selama 30 hari

\section{Analisis Perbandingan}

Analisis perbandingan dilakukan dengan membandingkan hasil produksi dari model awal dan hasil produksi dari model perbaikan
Tabel 4. Hasil produksi model awal dan hasil produksi model perbaikan

\begin{tabular}{|c|c|c|c|c|}
\hline \multirow{2}{*}{ Days } & \multicolumn{2}{|c|}{ Model awal } & \multicolumn{2}{c|}{$\begin{array}{c}\text { Model } \\
\text { perbaikan }\end{array}$} \\
\cline { 2 - 5 } & ROLL & TON & ROLL & TON \\
\hline 1 & 23 & 161 & 36 & 252 \\
\hline 2 & 22 & 154 & 40 & 280 \\
\hline 3 & 18 & 126 & 36 & 252 \\
\hline 4 & 18 & 126 & 28 & 196 \\
\hline 5 & 21 & 147 & 30 & 210 \\
\hline 6 & 25 & 175 & 31 & 217 \\
\hline 7 & 31 & 217 & 37 & 259 \\
\hline 8 & 19 & 133 & 40 & 280 \\
\hline 9 & 19 & 133 & 36 & 252 \\
\hline 10 & 22 & 154 & 40 & 280 \\
\hline 11 & 21 & 147 & 32 & 224 \\
\hline 12 & 22 & 154 & 34 & 238 \\
\hline 13 & 21 & 147 & 32 & 224 \\
\hline 14 & 20 & 140 & 33 & 231 \\
\hline 15 & 17 & 119 & 35 & 245 \\
\hline 16 & 23 & 161 & 38 & 266 \\
\hline 17 & 23 & 161 & 40 & 280 \\
\hline 18 & 25 & 175 & 37 & 259 \\
\hline 19 & 26 & 182 & 38 & 266 \\
\hline 20 & 17 & 119 & 35 & 245 \\
\hline 21 & 27 & 189 & 25 & 175 \\
\hline 22 & 24 & 168 & 36 & 252 \\
\hline 23 & 24 & 168 & 39 & 273 \\
\hline 24 & 26 & 182 & 44 & 308 \\
\hline 25 & 22 & 154 & 29 & 203 \\
\hline 26 & 24 & 168 & 34 & 238 \\
\hline 27 & 24 & 168 & 42 & 294 \\
\hline 28 & 24 & 168 & 33 & 231 \\
\hline 29 & 23 & 161 & 40 & 280 \\
\hline 30 & 24 & 168 & 32 & 224 \\
\hline AVG & 22,5 & 157,5 & 35,4 & 247,8 \\
\hline MIN & 17 & 119 & 25 & 175 \\
\hline MAX & 31 & 217 & 44 & 308 \\
\hline
\end{tabular}

Pembuatan analisis grafik pada gambar 4.8 bertujuan untuk mengetahui bahwa data output model 
perbaikan cenderung menghasilkan output lebih tinggi dengan rata rata 35.4 mini roll perhari dan output terendah terjadi di hari ke 21 dengan output sebesar 25 mini roll sedangkan output tertinggi terjadi di hari ke 24 dengan output sebesar 44 mini roll. Untuk model model awal output yang dihasilkan cenderung dibawah output model perbaikan dengan rata rata 22.5 mini roll perhari dan output terendah terjadi dihari ke 15 dan 20 dengan output sebesar 17 miniroll sedangkan output tertinggi terjadi dihari ke 7 dengan output sebesar 31 mini roll tinggi dari model awal kecuali di hari ke 21 model usulan mengahasilkan output 25 mini roll dan model awal menghasilkan 27 mini roll. Berdasarkan rata-rata dari output model perbaikan mengalami kenaikan sebesar 12.9 mini roll atau 90.3 ton, apabila angka kenaikan output dikemas dalam bentuk persentase maka kenaikan output sebesar 57.3\%.

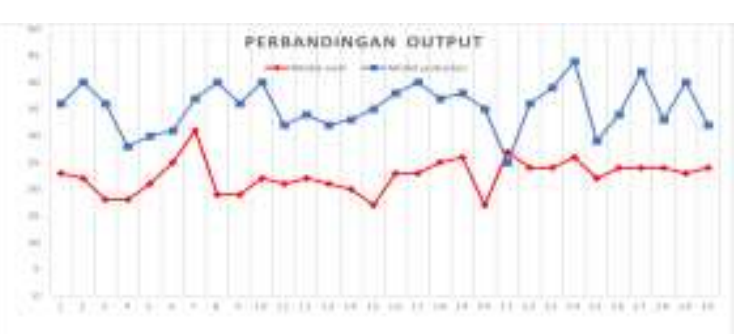

Gambar 3. Grafik perbandingan input

\section{PENUTUP}

Telah di dapat variabel yang mempengaruhi kapasitas produksi di PT XYZ dengan menggunakan metode discrete event simulation yang diawali dengan pembuatan model awal yang sudah tervalidasi sehingga model simulasi dapat mewakili sistem dunia nyata, dari hasil analisis model awal ditemukan variabel yaitu faktor utilitas checker (kelompok kerja pembongkran ballpress) yang terdiri dari 4 orang tenaga kerja dengan rata-rata dari jumlah antrian ballpress tersebut sebesar 4.0473., rata rata dari jumlah ballpress dalam sistem sebesar -1.8130 , rata-rata waktu tunggu yang terjadi dalam antrian sebesar -0.0201 . rata-rata waktu tunggu ballpress yang sedang dilayani sebesar -0.0090 , dan probabilitas layanan sebesar 2.2342 sedangkan standart probabilitas waktu sibuk adalah $0>1$ maka dapat diartikan bahwa waktu sibuk dari checker adalah 2 kali lipat dari jam normal. Simbol minus pada long queue, long system, waiting queue, waiting system menandakan bahwa kurangnya fasilitas pelayanan atau tenaga kerja sehingga perlu adanya penambahan jumlah tenaga kerja pada checker (kelompok kerja pembongkaran ballpress). Kemudian dilanjutkan dengan menyusun model perbaikan berdasarkan model variabel yang telah di analisis dan identifikasi kemudian output hasil simulasi model awal dibandingkan dengan hasil simulasi model perbaikan. Sehingga model perbaikan dapat dijadikan sebagai usulan untuk meningkatkan hasil produksi.
Dari hasil simulasi model perbaikan output yang dihasilkan mengalami peningkatan sebesar 35.4 mini roll atau setara dengan 247.8 ton, sedangkan pada pada kondisi aktual output yang dihasilkan hanya 22.5 mini roll atau setara dengan 157.5 ton. Artinya terjadilah peningkatan hasil produksi sebesar 12.9 mini roll atau 90.3 ton, apabila angka tersebut dikemas secara persentase maka terjadi peningkatan produksi sebesar 57.3\% dari kondisi aktual. Angka ini menunjukan rata rata output produksi per harinya.

\section{DAFTAR PUSTAKA}

Ariyanti, Anisa Tri. (2016). Makalah Teori Produksi. http://anisasdp23.blogspot.com. Diakses pada 16 Januari

Pasirulloh, M. A. (2017). Pemodelan Dan Simulasi Sistem Industri Manufaktur Menggunakan Metode Simulasi Hybrid (Studi Kasus: PT. Kelola Mina Laut). Institut Teknologi Sepuluh Nopember.

Perdana, T. (2014). SIMULASI KEJADIAN DISKRET PADA PERANCANGAN MANAJEMEN LOGISTIK DI UNIT LAYANAN LOGISTIK PERTANIAN: STUDI KASUS DI KECAMATAN PANGALENGAN KABUPATEN BANDUNG. Sosiohumaniora, 16(1), 14-21.

Prasetyo, H., \& Liquiddanu, E. (n.d.). Optimasi Jumlah Operator dengan Metode Simulasi Arena: Studi Kasus pada Stasiun Kerja Pengecatan Sheet Metal Fabrication.

Riyanto, O. A. W. (2016). Simulasi Model Sistem Kerja Pada Departemen Injection Untuk Meminimasi Waktu Work-In-Process. Jurnal Ilmiah Teknik Industri, 15(1), 69-78.

Rustam, L. (2017). Pengembangan Model Simulasi Diskrit terhadap Perencanaan Produksi pada IKM 88 Marijo. Journal of Industrial Engineering Management, 1(2), 30-34.

Santoso, A. A., \& Fudhla, A. F. (2019). Perbaikan Sistem Produksi Kardus Dengan Pendekatan Lean Dmai Di Pt Kedawung Ccb. JISO: Journal of Industrial and Systems Optimization, 1(1), $39-46$.

Suprianto, S., Muhammad, M., \& Indriani, A. (2018). Penerapan Metode Simulasi Kejadian Diskrit Pada Layanan Antar Pesan. In Seminar Nasional Pendidikan Teknik Informatika (SENAPATI) (Vol. 9, pp. 205-210). 